\title{
The kyai's voice and the Arabic Qur'an Translation, orality, and print in modern Java
}

\author{
JOHANNA PINK
}

\begin{abstract}
This paper discusses practices of translating the Qur'an into Javanese in the Indonesian post-independence era. Focusing on works that emerged in pedagogical contexts, it demonstrates that the range of translation practices goes far beyond contemporary notions of scriptural translation. I argue that this is due to the oral origin of these practices and to the functions they assume in teaching contexts. These result in a higher visibility of the translator who appears as a religious authority in his ${ }^{1}$ own right. His voice might therefore be considered a valuable contribution to the translation, rather than a distortion of the source text's true meaning. These dynamics are tied to the status of Javanese in a country in which the predominant language of print is Indonesian. Studying translation activities in languages without official status in the nation-state period contributes to widening our perspective on contemporary translation practices.

KEYWORDS

Translation; Qur'an; Java; Javanese; pesantren; education; Islam; kitab kuning; orality.
\end{abstract}

\section{INTRODUCTION}

Prior to Indonesian independence, Javanese was the language with the largest number of speakers in the Indonesian archipelago. Since 1945, when the Indonesian language was made the newly-founded Republic of Indonesia's only official language, Javanese, like all regional vernaculars, has been increasingly marginalized in public space (Woodward 2014: 14-19). The

${ }^{1}$ Since Qur' an translation is predominantly a male endeavour, especially in Indonesia, and all the translators discussed in this paper identify as male, I will use the male form of the personal pronoun.

JOHANNA PINK is professor of Islamic Studies at the Albert-Ludwigs-Universität Freiburg, Germany. Her main fields of interest are the transregional history of tafsir , especially in the modern period, and Qur'an translations with a particular focus on Indonesia. Her publications include a guest-edited volume of the Journal of Qur'anic Studies Vol. 17/3 (October 2015) "Translations of the Qur'an in Muslim majority contexts". Her latest monograph is entitled Muslim Qur'ānic interpretation today; Media, genealogies, and interpretive communities (Bristol: Equinox, 2019). Johanna Pink can be reached at: johanna.pink@orient.uni-freiburg.de.

(C) 2020 Faculty of Humanities, Universitas Indonesia JOHANNA PINK | DOI: 10.17510/wacana.v21i3.948. 
field of translation is no exception to this marginalization. Since the media and publishing market are dominated by Indonesian-language output and most formal education is conducted in Indonesian as well, it stands to reason that literature in foreign languages would primarily be translated into the Indonesian language at the expense of Javanese and other regional languages.

Consequently, when the Indonesian Ministry of Religion started the production of an official Qur'an translation in the 1960s, it was into Bahasa Indonesia only. The government translation has seen several editions, dominates the market and is the main point of reference of Indonesian Qur'an translation; the recent efforts of the Ministry to produce Qur'an translations into regional languages and thereby contribute to their revival has done little to change that (Lukman 2019).

And yet, Javanese Qur'an translation has prevailed. New works of Qur'an translation in the Javanese language have been published in the postindependence period and continue to be written, not by the state, nor by large committees of scholars such as those that produce the Ministry translations, but by individuals. Many of those individuals are teachers, which is no coincidence because the field of Islamic religious education - be it in mosques or Islamic boarding schools, the pesantren - is an important locus of the continuing use of Javanese.

The corpus of Javanese Qur'an translations that have been produced in a teaching context in the post-independence period and published in print is not large but it is distinct due to its roots in specific modes of teaching the Qur'an. Many of these works prefer the label tafsir - 'explanation' or 'interpretation' - to that of translation or tarjamah. Such labels are not always indicative of the method and content of a given work and, as such, have limited analytical value. They do, however, raise the question what defines a Qur' an translation and what distinguishes it from an interpretation of the Qur'an or a Qur'anic commentary; and that question will come up in this paper repeatedly.

What are we to make of the Javanese kyai Bisri Musthofa's Al-Ibriz lima'rifat Tafsir al-Qur'än al-'aziz ('Pure gold regarding the knowledge of the interpretation of the Qur'an'), for example, a work that, by its title, does not presume to be a translation and that uses ample embellishment when rendering the meaning of the Qur'an (Muștafā n.d.; Musthofa 2015)? This becomes obvious when we consider Bisri Musthofa's treatment of the story of Abraham's dispute with an unnamed ruler, presumably Nimrod, which is originally told very briefly in $\mathrm{Q} 2: 258$ :

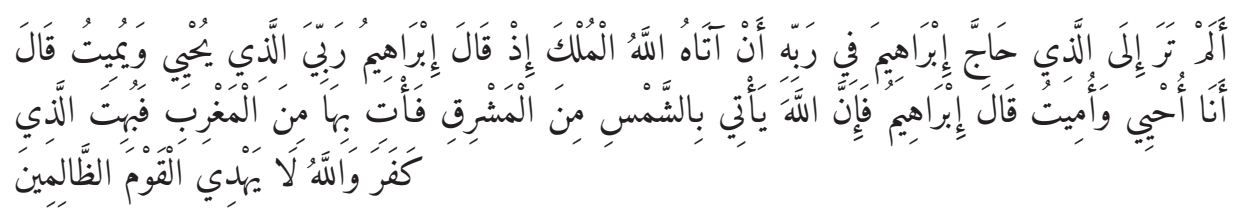

'Have you not thought about the man who disputed with Abraham about his Lord, because God had given him power to rule? When Abraham said, "It is my 
Lord who gives life and death," he said, "I too give life and death." Abraham said, "God brings the sun from the east; so bring it from the west." The disbeliever was dumbfounded. God does not guide those who do evil.'

Al-Ibriz renders it thus:

Raja Namrudh tau ngajak bantahan karo Nabi Ibrahim 'alaihissalam. Raja Namrudh takon mengkene: He Ibrahim! Pengeranmu kang mbok kandhak-kandhakake iku sapa? Nabi Ibrahim: Pengeran kula inggih punika ingkang damel gesang lan damel pati. Namrut: Yen mengkono ya aku iki, sebab ingsun bisa nguripi lan bisa mateni. (Nuli Raja Namrudh nimbali wong lanang loro kang siji dipateni kang sing siji ora den pateni.) Nabi Ibrahim nuli dhawuh maneh Allah Ta'ala ngetokake srengenge saking wetan, menawi saestu sampean Pengeran mbok inggih sampeyan tekakaken saking kilen. Raja Namrudh nuli mak cep ora bisa guneman. ${ }^{3}$

'King Nimrod started a dispute with the Prophet Abraham, Peace be upon him. King Nimrod asked, "Abraham! Who is your Lord whom you are talking about?" The Prophet Abraham [said], "My Lord is the one who provides life and provides death." Nimrod [said], "If that is the case, it is true for me as well, since I can let [people] live and I can kill [them]." (Then King Nimrod summoned two men, one of whom he killed and the other one he did not kill.) Then the Prophet Abraham said in turn, "Allah the Exalted lets the sun appear from the East; if you are truly a Lord, please bring it from the West." King Nimrod was then struck dumb, being unable to speak.'

This is a rather loose retelling of the story. It leaves out the theologically much-debated statement that God has given Abraham's interlocutor the power to rule, or sovereignty, or his kingdom (al-mulk). Conversely, it adds an initial question from Nimrod that the Qur'an only implies, and it identifies Abraham's interlocutor by a name not mentioned in the Qur'an. Despite taking these liberties, the exegete still follows the Qur'anic narrative fairly closely. There is only one substantial addition, according to which Nimrod brings two men and has one of them killed. This story is not found in the Qur'an but in standard Qur'anic commentaries (tafsir) such as the concise textbook-style Tafsìr al-Jalālayn (al-Mahallī and al-Suyūṭi 1385 H). Bisri Musthofa conscientiously marks it by a bracket to indicate that it is not part of the Qur'an text.

Now, is this work a translation or an interpretation? It is impossible to give a definite answer to this question for reasons that will become clear in

2 The English Qur'an translations in this paper are loosely based on those by M.A.S. Abdel Haleem (2008) and Alan Jones (2007) but have been adapted to best capture the exegetical problems as seen by the Javanese translators. In general, in order not to bloat the number of references in this paper, for citations from Qur'an translations and Qur'anic commentaries, the edition used will be mentioned at the first occurrence, after which the citation will be by sura and verse in the Qur'an. Arabic quotations from the Qur'an follow the reading by Hafs 'an 'Āșim which is the standard version used in Indonesia.

${ }^{3}$ This is a transliteration of the pegon edition of Al-Ibriz into standard Javanese spelling which differs from the more phonetic spelling in the Latin-script edition of the same work. 
the course of this paper. Nonetheless, it deserves some consideration prior to the in-depth analysis of Javanese kyais' translation practices.

\section{JOSEPH'S DREAM: THE QUR' AN TRANSLATED AND INTERPRETED}

Qur'an 12:4 is the start of the story of Joseph. In the verse, Joseph tells his father - Jacob, although the Qur' an does not mention his name here - about a dream he had:

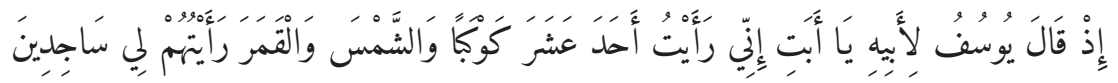

There are myriad ways to render this verse in English. The following are but three of them:

Joseph said to his father, "Father, I dreamed of eleven stars and the sun and the moon: I saw them all bow down before me." (Abdel Haleem 2008)

When Yusuf said to his father: "O my father! surely I saw eleven stars and the sun and the moon- I saw them making obeisance to me." (Shakir 2009)

(It happened) when Yusuf said to his father, "My father, I saw (in dream) eleven stars and the Sun and the Moon; I saw them all fallen prostrate before me." (Usmani 2007)

These translations differ from each other noticeably, as we would expect. Ambiguities in the source text, the nonexistence of precise equivalents in the target language, and the individual translators' preferences are among the reasons why no two translators will end up with the same translation. There are too many choices to make. For example, should we literally translate the particle $i d h$ ('when') at the beginning of the sentence, even if the resulting sentence is syntactically incorrect in English, or omit it, or add a main clause to complete the sentence? Should we translate the Arabic Yūsuf as an English Joseph or an Islamized Yusuf? Should we render the Arabic verb ra'aytu according to its basic meaning as 'I saw' or according to the meaning that it clearly has in this verse, which is 'I dreamed'? Is the Arabic verb sajada best represented by the technical equivalent 'to fall prostrate' or by the more easily comprehensible 'to bow down' or should the interpretive significance of this word, in the sense of expressing obedience, be privileged, as M.H. Shakir has decided to do?

Before we get lost in detail, however, an important observation should be made: the three translations have much more in common than divides them. They are far closer to each other than they are to Bisri Musthofa's abovementioned $\mathrm{Al}-\mathrm{Ibriz}$. All of them are part of a genre of text that is characterized by an extreme closeness to the source text and a reluctance to depart from it. We immediately recognize all three English renderings of the Qur'an as "translations" because they follow the structure and semantic content of the source text as faithfully as is possible without violating the rules of the target language. The translators strive not to add anything to the text; or if they do, 
they mark these additions clearly, as Taqi Usmani does through his use of brackets. None of them adds pieces of dialogue or decides to omit problematic statements.

Thus, these texts are considered translations because they ostensibly privilege the source text over the translator's ideas or any other content that is external to the source text. The translations either strive to make the translator invisible or they clearly separate his contribution from the "translation proper" by brackets that divide the translator from the rendering of the source text. Translation strategies might vary and might range from a word-for-word rendering of the source text to the reconstruction of its meaning in a different linguistic and cultural context but they certainly do not include the translator showcasing his opinion about what is missing from the source text and mixing that opinion with the translation. Nor would the translator try to improve the narrative and enhance its emotional impact by adding rhetorical devices and embellishments to the text that are purely his own. At the same time, they make sure to produce a text that can stand alone and be read on its own; due to its demonstrative closeness to the source text, it may be considered an adequate, albeit imperfect, substitute.

Qur'an translations in the sense represented by the English renderings above constitute a genre of text that suggests the absence of interpretations or their clear demarcation from the translated text. This understanding of a translation, however, is a very narrow one which stems from European practices of Biblical translation. Restricting the concept of translation to works that conform to this understanding would fail to capture the diversity of translation practices, both historically and in the contemporary period, across the globe. ${ }^{4}$ Limiting the study of Qur'an translations to this specific genre of text would mean excluding much of the Muslim engagement with the Qur'an in vernacular languages that took place before the early twentieth century, and important parts of the more recent vernacular engagement with the Qur'an as well - including the field of Javanese educational exegesis.

Moreover, when defining one type of translation as being particularly faithful to the source text, one problem is usually ignored: the translator's invisibility does not mean that the translator is absent; he is merely well hidden. However much the translator's contribution might be obscured in the translation, it is still there; it is merely next to impossible for the reader to trace it. Every translation, however "literal" it might strive to be, is a product of the choices made by the translator and, as such, an interpretation. ${ }^{5}$

${ }^{4}$ Regarding this perspective on translation and the resulting critical view of translation studies, I am very much indebted to Maria Tymoczko's work (see especially Tymoczko 2007). On the local meanings of translation and the related terminology in Javanese culture between the eighteenth and the early twentieth centuries, see Ricci 2010.

${ }^{5}$ Many Qur'an translators are, in fact, aware of this and label their works accordingly, from Arthur J. Arberry's The Qur'an interpreted (1955) to the Saudi King Fahd Complex's Interpretation of the meanings of the noble Qur'an, which is often called the "Hilali-Khan translation". Regardless of this label, their works closely follow the source text and are therefore typically perceived as translations whereas Qur'anic interpretations "proper" are usually expected to contain a 
Even those translators who shirk away from omitting a part of the text or making insertions without highlighting them have ample opportunity to make semantic or syntactic decisions that fit their own vision of what the Qur'an means.

Translation practices that deviate from the pattern described above might offer different options of handling the involvement of the translator and therefore expand our perspective on what constitutes a "faithful" translation. Moving away from the paradigm of Biblical translation, the act of translation ceases to appear "as an exact science that could strive for or even achieve equivalence, but rather as a creative, imaginative, and political act that" reflects "a range of local agendas, expectations, and priorities" (Ricci 2014: 544).

If we treat translations, in this broader sense, as a transfer of meaning from one language and cultural context to another, we find that there is a wide range of practices that fit the bill. Some of the practices we find in Javanese literature, especially in the field of teaching, do not involve rendering the translator invisible or distinguishing clearly between the translator and the translated text. And yet, their focus is on giving access to the Arabic Qur'an to an audience that does not speak Arabic and the focus of their texts is firmly on the source text, rather than on delivering a commentary on its interpretive tradition as we find it in the bulk of the Arabic tafsir literature. ${ }^{6}$

Javanese pedagogical Qur'an translations should thus be measured neither by the standards of the genre of Qur'an translation described above, which claims fidelity to the source text and aims to render the translator invisible, nor by those of scholarly Qur'anic commentaries. Rather, I propose to treat them as examples of specific translation practices indigenous to Java. As I hope my discussion will show, this is justifiable despite the fact that the majority of the authors avoid the label "translation" (tarjamah) and choose the label tafsir for their works instead. This is because in modern Indonesian usage, a "translation" is understood in a narrow sense to be a work that is in line with the model of Biblical translation, closely following the source text and blotting out the translator's voice. This, in turn, is often seen as dogmatically problematic with regard to the Qur'an because this model of translation is based on the notion of equivalence between source and target text. However, producing an equivalent to the sacred text in a language other than Arabic is impossible, from a mainstream Muslim perspective, due to the doctrine of the inimitability (ijäz) of the Arabic Qur'an (Martin 2002). The choice of the label tafsir by Muslim scholars for their works is therefore indicative of a restrictive understanding of translation as well as of dogmatic concerns whereas my analysis focusses on practices of rendering the Qur'an's meaning in Javanese, regardless of label.

\footnotetext{
larger and consistent amount of commentary in the author's own words.

${ }^{6}$ This is not the place to discuss the tradition tafsir, or the Qur'anic commentary. For an overview of the main features of this genre, see (Calder 1993; Saleh 2004). The term tafsir is spelled in transliterated Arabic (tafsir) when referring to a genre of Islamic scholarship or a Qur'anic commentary and in Indonesian spelling (tafsir) when referring to an Indonesian or Javanese book title or term used to categorize a book.
} 
In the following sections, I will analyse four such Javanese renderings of the Qur'an with a focus on the translation practices they represent. My main interest will be in the aims of these translations, their relationship to the Arabic source text, and the role they expect this source text to assume for their audience, especially in pedagogical settings.

I am not looking at an exhaustive corpus of Javanese Qur'an translations here, which would hardly be feasible. My selection excludes manuscripts, texts that were published before Indonesian independence, and texts that have not been produced in a pedagogical context. ${ }^{7}$ Even within these parameters, some works might not have been available to me because there is a big market for "grey literature", many twentiethcentury translations are out of print, and few research libraries specialize in Javanese Islamic literature. Nevertheless, the four works I analyse allow me to evaluate a range of pedagogical translation practices. The most distinct of those, and the one that most brings the translator into the foreground, is closely tied to Islamic boarding schools, the pesantren, and their textbooks. ${ }^{8}$

\section{JAVANESE TEACHERS OF THE QUR' AN AND THEIR "YELLOW BOOKS"}

Those two Javanese works of tafsir that seem to be most commonly available in bookstores today belong to the category of textbooks called kitab kuning or 'yellow books'. These inexpensive books, produced for the use in pesantren, are named after the yellowish paper of early Middle Eastern prints. Some contemporary publishers of kitab kuning dye the edges of the books yellow in order to emphasize the continuity with the scholarly and educational tradition of the pesantren environment. The language of these books is often Arabic. Kitab kuning in Malay and other regional languages exist as well, in which case they are printed in Arabic script. For Javanese, this means the fully vowelized pegon variant. The label kitab kuning explicitly points to the use of the Arabic script. Latin-script books would be buku, rather than kitab, and would more commonly be written by Islamists or modernist religious intellectuals while kitab kuning are either classics from the tradition of Islamic religious learning or textbooks that have been written by traditional scholars, such as the kyais who are heads of a pesantren (Van Bruinessen 1990, 2020).

The pesantren curriculum has a heavy focus on Islamic law and, to a lesser degree, religious doctrine, as well as the teaching of classical Arabic which is needed to read the relevant texts. Tafsir , or Qur'anic interpretation, is not a core part of it. Before the twentieth century, this field of learning was mostly covered by the Tafsìr al-Jalālayn, a concise Qur'anic commentary in Arabic dating from the fifteenth century that has dominated the teaching of tafsir in many regions of the Islamic world for the past five centuries. Starting in the

\footnotetext{
7 For manuscripts, see Nurtawab 2009. Further works, such as al-Huda Tafsir Qur'an Basa Jawi by Bakri Syahid (1976) and the partial works by Moenawar Chalil, Tafsir Qur'an Hidaajatur-Rahmaan (juz' 1, 1958), and Ahmad Djawahir, Sekar Sari Kidung Rahayu, Sekar Macapat Terjemahanipun Juz Amma (1992), are mentioned in Nurtawab 2009, 2016; Masrur 2012; and Gusmian 2016.

${ }^{8}$ On the pesantren, see Van Bruinessen 2019a with further references.
} 
nineteenth century, Islamic modernism, promoting the direct engagement with the textual sources of Islam promoted an increased interest in hadith and Qur'anic studies, resulting in the production of a number of indigenous works of tafsir in various languages spoken in Indonesia including Javanese. This was reflected in the growth of tafsir-related kitab kuning literature in the twentieth century although tafsir has not come close to rivalling figh (Van Bruinessen 1990; Nurtawab 2009).

The two kitab kuning I discuss in this section are representatives of a paradigmatically Javanese genre of Qur'an translation. They are situated in a specific social space, that of the pesantren, and closely tied to the authority of the kyai, or teacher, who authored them, which might transcend the boundaries of his school (Van Bruinessen 2019b).

The two kyais who wrote the most well-known and widely available kitab kuning on the Qur'an were brothers. Both were married to daughters or granddaughters of pesantren leaders whose schools they eventually took over, Bisri Musthofa (1915-1977) in Rembang in Central Java and Misbah Mustofa (1916-1994) in Bangilan in East Java. ${ }^{9}$

The more famous one of them was Bisri. His above-mentioned Al-Ibriz li-ma'rifat al-Qur'ān al-'aziz was first published in Rembang in 1959 in pegon script, at a time when Javanese was still very much the main language of the inhabitants of most regions of Java. A more recent, undated pegon edition that is still on sale has three volumes. In 2011, a one-volume glossy Latin-script version with gilded writing on the hardcover and colour print was published. That edition is quite obviously more than a textbook for pesantren students. Its luxurious presentation demonstrates the prestige of this work and of its author - or possibly the author's son, A. Mustofa Bisri, "Gus Mus" (b. 1944), who continues to teach al-Ibriz at the pesantren in Rembang that his father had headed since the 1930s. Bisri Musthofa was associated with the Nahdlatul Ulama and so is Gus Mus (Van Bruinessen 1990; KH Bisri Musthofa 2015; Wahidi 2015; Tafsir Al-Ibriz 2020; Sejarah dan Biografi 2020).

Misbah was the younger brother of Bisri. He wrote his Al-Iklil fi ma'anni al-tanzil ('The Crown regarding the meanings of revelation') between 1977 and 1985. It was subsequently published in Surabaya in an undated soft cover edition in thirty parts, conforming to the thirty parts of the Qur'an (Supriyanto 2016).

Both kyais are clearly familiar with the classical pesantren textbook of tafsir, the Tafsì al-Jalälayn, as is obvious from the relatively high degree of overlap regarding semantic and narrative, and occasionally grammatical, explanations. But they do not consistently or exclusively draw on the Tafsìr al-Jalālayn, and their methodology could not be more different. The Jalalayn is, essentially, an expanded version of the Qur'an for students who understand Arabic. For example, Q 12:4, the verse on Joseph's dream, is treated in the Jalälayn as follows, with the Qur' anic wording underlined:

\footnotetext{
9 The differences in spelling the originally Arabic name Mușțafā go back to the authors' own spelling of that name in Latin script.
} 
Mention when Joseph said to his father Jacob, "O my father [there follows a brief grammatical explanation of the form 'my father' takes in Arabic], verily, I saw in my dream eleven stars and the sun and the moon: I saw them, which is repeated for affirmation, bow down before me; here, the plural form for sentient beings is used for celestial bodies because prostration is an attribute of sentient beings.

This is a mix of semantic and grammatical explanation as well as the occasional brief exegetical addition, such as the name of an unnamed character in the Qur'an. Al-Ibriz and Al-Iklìl, conversely, completely separate these three elements from each other and from the Arabic Qur'an. Accordingly, they employ a tripartite structure that is based on a combination of different methods used in pesantren teaching. Their layout differs but the three parts and their characteristics are present in both (see Figures 1 and 2).

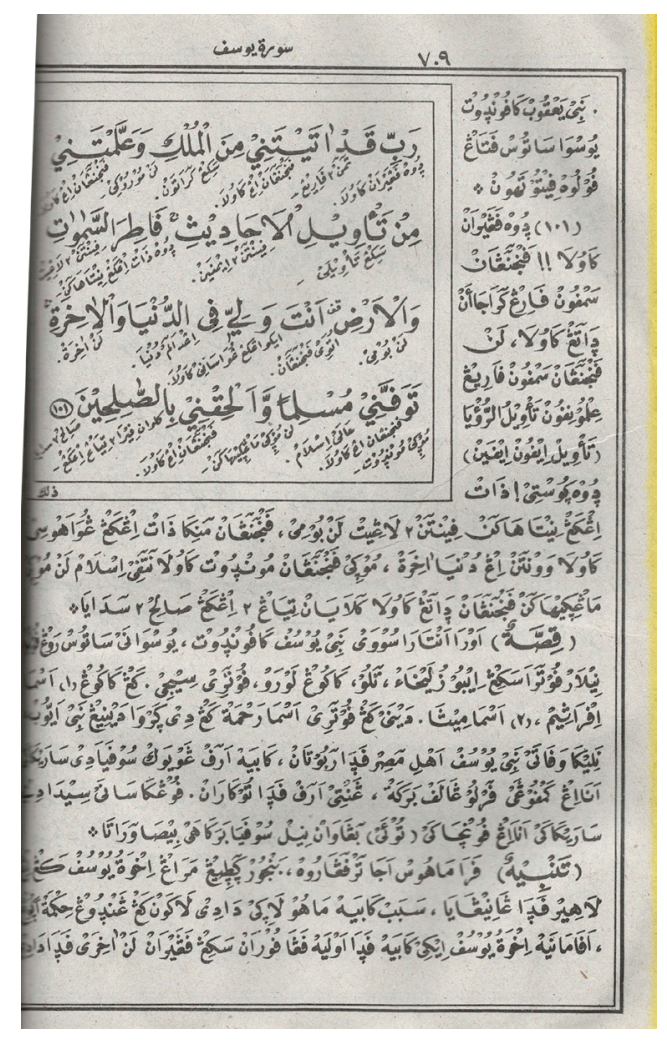

Figure 1. Page from a pegon edition of Al-Ibriz. 


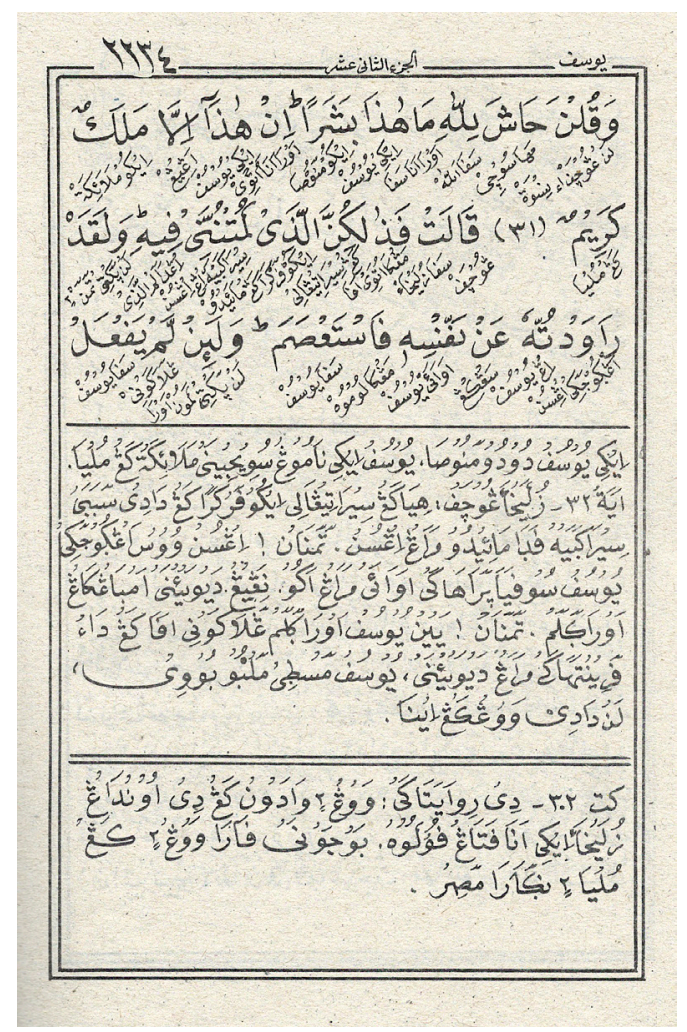

Figure 2. Page from Al-Iklīl.

The first part, either at the top or in a box at the upper and inner margin of the page, is devoted to the Arabic text of the Qur'an alongside an interlinear word-for-word translation according to a method called gandul, about which more will be said in the next section.

In the second part, either in the middle of the page or in the outer and lower margins, the meaning of the verses is rendered verse by verse in the exegete's own words.

The third part contains additional information. In the case of Al-Iklill, it is provided at the bottom of the page, marked as $k t$ in Arabic letters (short for keterangan or 'explanation') and separated from the first two parts by a double horizontal line. Al-Ibriz delivers this information after the Javanese rendering of an individual verse, below a bold-faced Arabic header such as qișa 'story', fä ida 'benefit; meaning', or tanbīh 'remark'. This additional material includes narratives, reports about the Prophet (hadiths), digressions into related topics, explanations by authoritative religious scholars, and details about the content of the verse, such as the number of an unnumbered quantity of items or the name of an unnamed person. Neither of the two commentaries offers such additions to every verse. Their frequency and length are a little higher in $\mathrm{Al}$ Iklï than in Al-Ibriz. For example, concerning Q12:4, Al-Iklìl specifies Joseph's age at the time he had the dream; the day of the week and the day in the 
Islamic calendar on which it took place; the meaning of the dream; a hadith on Joseph's excellence; the epic age reached by the protagonists of the story; and the names of the planets seen by Joseph in his dream. Related to the subsequent verse, Al-Iklil offers an excursus of eight pages on the nature of dreams, the distinction between divine and Satanic dreams, and the characteristics of persons who receive divine dreams. In Al-Ibriz, such material is a little more infrequent and often not as extensive. But even Al-Iklïl has long segments of the Qur' an without any commentary.

While the third part is what most clearly qualifies the two works as Qur'anic commentaries, rather than translations, it is also the most inconsistent and marginal part of them. The first two parts are much more prominent. They cover the entire Qur'an, and provide access to its meaning, and as such, they are what justifies the treatment of Al-Ibriz and Al-Iklil as Qur'an translations. Strictly speaking, these works even contain two different translations each: they offer first a word-for-word-translation of the source text, and second, a paraphrase of its meaning. These correspond broadly to what Ricci (2014), in her analysis of Malay and Javanese translation practices, has categorized as sentence-level and interlinear translation (2014: 548-553) although the translators use the Qur' anic verse, rather than the sentence, as a structural unit.

That twofold structure is an ingenuous solution to the old debate between two types of translation. In Roman antiquity, the first method, verbum pro verbo, was applied by the grammarians while the second, sensus pro senso, was the domain of rhetoricians. These two methods have different goals. The first aims to enable the reader to understand the source text, precisely and with all its grammatical forms, syntactic constructs and semantic nuances. The second conveys meaning in the target language fluently and rhetorically adequately, even if this means digressing from the structure of the source text. In short, the first method is concerned with understanding a text, the second with producing a text. The decision between these two methods and their corresponding aims has always been particularly challenging when a sacred Scripture was concerned, where precision was often privileged over eloquence and any attempt to reproduce the source text's rhetoric might be construed as sacrilegious (Gipper 2014).

The Javanese pesantren tafsirs refuse to achieve one goal at the expense of the other. They employ both methods side by side and thereby manage to satisfy both concerns, the grammatical and the rhetorical. None of the ways in which they achieve this, however, conform to the standard model of translation represented by the English Qur'an translations cited above, as will become clear from the two following sections.

\section{GANDUL: GRAMMATICAL TRANSLATION FROM ORAL TEACHING TO PRINT}

Interlinear translation has historically been a common type of Qur'an translation that has, in all likelihood, frequently been used in pedagogical settings. It essentially consists of notes in between the lines of the muṣaf, the Arabic Qur'an, in a vernacular language. In a manuscript culture, this was 
an easy way to supplement a copy of the Arabic Qur'an with explanatory content (Zadeh 2012: 16-19).

At a superficial glance, one might assume that this once pervasive type of translation has completely fallen out of use in the age of print and been replaced by the "modern" type of translation that is modelled after Biblical translations and uses the grouped-style layout typical of printed books. Muhammad Ali's English Qur' an translation of 1917 that has been translated by Indonesians into Dutch, Javanese, and Bahasa Indonesia (in this order) was a trendsetter in this regard, with the Arabic and the English text in adjacent columns (Ali 1917; Burhani 2015). A similar layout was adopted by the Indonesian Ministry of Religion and many other Indonesian Qur'an translations, and for a while, it indeed seems to have to put the old-fashioned interlinear translation, which was difficult to reproduce in print, clean out of use (Departemen Agama Republik Indonesia 1965). Interlinear translations have also received little attention in scholarship and have rarely been studied as religious texts in their own right (Ricci 2016: 70).

Today, however, given the availability of digital typesetting and an increased interest in the recitation of the Qur'an in Indonesia, numerous editions of the mushaf on glossy paper feature interlinear translations as well as transliterations (Pink 2017). There has clearly been a resurgence of the interlinear Qur' an translation in Bahasa Indonesia. In Javanese, as Al-Ibriz and Al-Iklìl show, it has never been out of use because the system of pedagogy it is embedded in has never been out of use either. That system is primarily an oral system: the kyai teaches children to recite the Qur'an and explains the meaning of the individual words as he does so. The teacher first recites the Arabic verse and then each individual word, along with a Javanese explanation; the children memorize the lesson. The interlinear translation found in Al-Ibriz and Al-Iklil is the printed embodiment of that oral system of teaching and learning. It also reflects the history of translating Islamic texts into Javanese, where interlinear translations have always been a central component, embedded in a culture of teaching religious knowledge alongside the Arabic language (Ricci 2014: 554).

The gandul system as it is employed in Javanese pesantren, like most forms of interlinear translation, does not deliver a coherent and grammatically correct text. Rather, it deals with each Arabic word individually, in a highly idiosyncratic manner. In contrast to most premodern and contemporary interlinear translations, it provides readers not only with the meaning but also the grammatical form and syntactical function of words (Gusmian 2015: 173-179).

Therefore, the gandul system is quite complex and is not quickly and easily understood. Indicators point out whether a word is the subject or an object, a participle, a plural form, a verb in the past tense, where a subordinate clause starts and ends, and so forth. If the subject or object is missing or takes the form of a pronoun, it is spelled out in the translation; for example, if the Qur'an says "Then they took him away with them", the interlinear translation will inform students that it is the brothers of Joseph who took Joseph away 


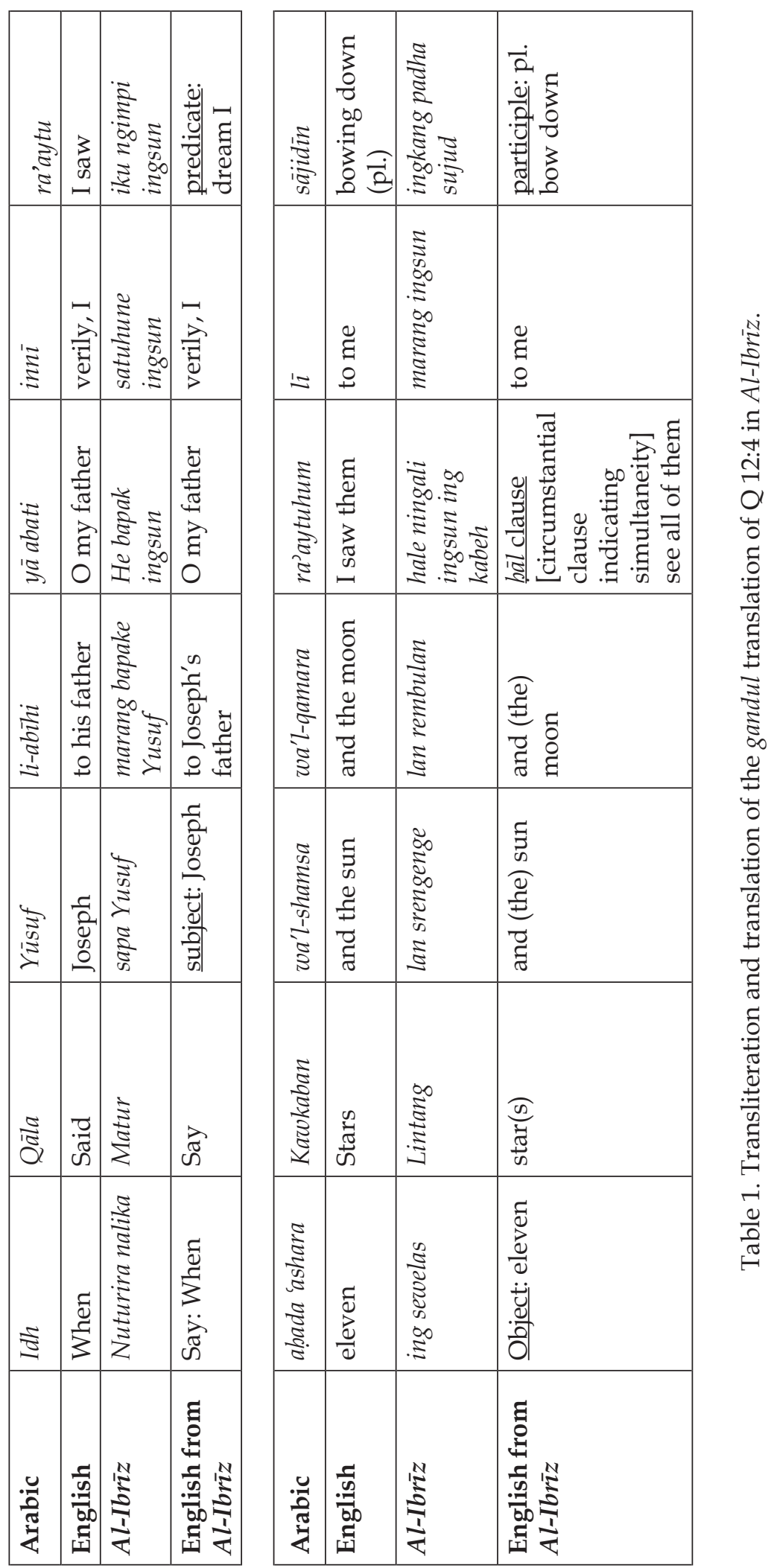


with them, that is, the brothers of Joseph. The structure of the grammatical explanations reflects the oral nature of the lessons, with question words such as "who?" and "what?" marking subjects and objects; it probably emerged from a Q\&A style that became formalized over time.

Table 1 shows how Q 12:4 (“When Joseph said to his father, 'O my father, verily, I saw eleven stars and the sun and the moon: I saw them all bow down before me.'") is treated by Al-Ibriz. Grammatical terms provided by the translation are underlined.

Al-Iklil follows a fairly similar pattern which is unsurprising because the sapa - iku - ing structure for indicating subject, predicate, and object is a standard of the genre (Gusmian 2015:173-179). At the same time, the two kyais have their idiosyncrasies and prioritize different grammatical and syntactical aspects in their explanations. ${ }^{10}$ Thus, gandul is an established and standardized system but it allows for flexibility. This type of interlinear translation might be a rather technical affair that does not involve any kind of literary ambition nor produce a coherent text but it still gives the kyais some space to make their individual voice heard.

That it is the kyai speaking in the word-for-word translation, and that the gandul translation is completely independent of the paraphrase delivered below it or side by side with it, is apparent from the exegetes' peculiar use of register. Register is probably the most characteristic feature of Javanese grammar. Depending on the relative position of speaker and addressee in the social hierarchy, different registers have to be used. Ngoko is for informal speech to peers of persons of lower rank and krama for persons of higher rank or, as a token of politeness, strangers. Registers have their own vocabulary and morphology and may not be mixed up. Moreover, sets of humilific (krama andhap) and honorific (krama inggil) words allow for an even more nuanced description of social hierarchies, for example when talking to a peer about a higher-ranking third person. While the use of registers has receded somewhat in recent decades, it was still very much a feature of spoken and written Javanese at the time Al-Ibriz and, to a slightly lesser extent, Al-Iklil were written.

The difference of register is reflected in the commentaries, as one would expect - but it barely appears in the gandul section whereas it is very much a part of the kyais' paraphrase of the Qur'an. There, they pay attention to the required variation of register whenever direct speech occurs in the Qur'an, such as in Joseph's conversation with his father. Although Al-Iklìl is generally much more prone to using the informal register of ngoko than Al-Ibriz, both

\footnotetext{
${ }^{10}$ For example, in the translation of Q 12:4, Al-Iklīl does not specify the $h \bar{a} l$ clause but places more emphasis on the relationship between the parts of the sentence. The author, Misbah Mustofa, has an elaborate system of cross-references indicating the referent of pronouns and similar constructs. In the verse above, he uses that system to explain that "them" (-hum) in "I saw them" (ra'aytuhum) refers to the eleven stars "and" the sun "and" the moon. He also points out when nouns are grammatically used to specify numbers or verbs (tamyiz in Arabic grammar, indicated by the Javanese apane) even when this is fairly obvious. Al-Ibriz, on the other hand, more often specifies the subject of a verb when explaining the verb than Al-Iklil does.
} 
translators unanimously have Joseph use krama when addressing his father because the hierarchy between them is exceedingly clear. The same is true for humans addressing God: there is no question of using ngoko in this case. Honorifics and humilifics are also frequently employed in the kyais' narrative.

Not so in the gandul section. Here, the translators use ngoko nearly exclusively even when a son addresses his father and the paraphrase of the same verse on the same page employs the adequate register of krama. Obviously, the word-for-word translation, gandul style, is conceived not as a reconstruction of something a person would say to another person, but as a technical explanation of the Arabic dialogue. We are listening not to the Qur'an but to the teacher's voice when addressing his students, which he, of course, does in ngoko because he is their elder and superior. The occasional stray humilific, honorofic, or krama terms occur but they are the exception, rather than the rule. The kyais are clearly concerned with the Arabic rather than the Javanese text here; their gandul translation does not need to be coherent nor does it need to conform to the Javanese codes of polite speech.

Given that the kyais focus so strongly on the Arabic text of the Qur' an with all its grammatical and syntactic details, it is all the more striking that there is one aspect of Arabic grammar to which both kyais devote very little attention, and that is the tense of the Arabic verbs. This is true for both sections of their translation, but even more so for the gandul section despite the fact that it is so ostensibly grammar-oriented.

The translators are able to avoid this issue because Javanese verbs do not have tenses. While it is possible to express them by adding words indicating that an action has taken place in the past or will take place in the future, this is not strictly necessary when that information is clear from the context. With regard to Q 12:4, it would certainly be obvious to listeners that this is a story about a past event and that Joseph, too, when he tells his father about his dream, talks about a past event. That does not quite explain why Al-Ibriz and Al-Iklil do not mention the fact that the Arabic verbs are in the past tense, though. After all, the two translators believe it necessary to specify many other things that should be equally obvious, such as the referent of some pronouns. When Joseph talks "to his father", they translate this as "to Joseph's father" just to exclude the unlikely possibility that someone else's father could be meant although it is entirely obvious from context that this is not the case. They do not care to pay remotely the same amount of attention to the tenses of verbs, if any.

While this might not always be necessary, in some cases, it might create confusion. For example, in Q 109:2-4, the same verb, 'abada ('to worship'), occurs eight times in different forms and tenses.

2 I do not worship ( $a$ budu) what you worship (ta budīn),

3 you do not/will not worship (antum 'äbidūn) what I worship (acudu),

4 I do not/will not worship (anā 'äbidun) what you have [always] worshipped ('abadtum),

5 you do not/will not worship (antum 'äbidīn) what I worship (abudu). 
This variation of the same verb, with some forms grammatically clear and others ambiguous, is so striking that Arabic Qur'anic commentaries typically discuss it in detail. Even the extremely concise Tafsir al-Jalälayn, which the two kyais were clearly familiar with, explicitly assigns tenses to some of the verbs: the present tense to verses two and three, and the future tense to the first parts of verse four and five. The Jalälayn fails to mention the past tense, possibly because it might have seemed obvious to readers who know Arabic grammar, but many other exegetes do. There is a consensus that the grammatically unambiguous form 'abadtum in the second part of verse four is in the past tense, and many exegetes even read the whole of verse four and the first part of verse five in the past tense.

The two kitab kuning translations, however, do not mention the past tense at any point, neither in the gandul section nor in the paraphrase. Al-Ibriz marks only the future tense and does so precisely where the Jalalayn does, that is, in the first parts of verses four and five. Al-Iklil uses the future tense in the paraphrase of the sura rather haphazardly but does not mention it once in the gandul section. Consequently, Misbah Musthofa translates three different Arabic verb forms in the same manner: tabudūn, antum 'äbidūn, and 'abadtum are all rendered as sira sembah ('you worship'), sometimes with and sometimes without a plural marker. Clearly, either the kyais' interest in the problem of tenses or their awareness of it are extremely limited.

One possible explanation for this lack of attention to the issue might be that the kyais are so preoccupied with the Arabic Qur'an and its grammar, especially so in the gandul section of their translations, that they fail to consider the characteristics of the Javanese language. In the case of tenses, the lack of reflection on the differences between Arabic and Javanese might cause an oversight. If the target language required the use of tenses, this might have forced them to carefully consider correct translation choices, but in Javanese, this is not the case.

Another possible explanation is the atomistic nature of the gandul system, meaning that the exegetes discuss each word by itself. A more holistic look at the complete sura 109 (Al-Käfirūn) might raise the question why the Qur'an uses the forms 'abadtum, antum 'äbidūn, and tabudūn for something that is uniformly translated into Javanese as 'you (pl.) worship'. In the gandul system, this is not done; it is sufficient to discuss a pre-defined set of formal characteristics word for word. In a way, the gandul system is an extreme form of the genealogical tradition of tafsir which has often been described by - and also criticized for - its atomistic verse-for-verse approach (Mir 1993). Within the logic of the gandul system, the translator is barely even interested in the whole verse but focuses on individual words.

\section{RHETORICAL TRANSLATION: NARRATIVE AND MEANING}

The second type of translation that is found in Al-Iklil and Al-Ibriz complements the atomistic gandul system by a more holistic approach. It delivers a paraphrase or re-narration of the Qur'anic text, verse for verse. For example, 
the two exegetes render Q12:4 ("When Joseph said to his father, 'O my father, verily, I saw eleven stars and the sun and the moon: I saw them bow down before me.'") as follows:

\begin{tabular}{|l|l|}
\hline \multicolumn{1}{|c|}{ Al-Ibrīz } & \multicolumn{1}{|c|}{ Al-Iklīl } \\
\hline $\begin{array}{l}\text { Siji dina Nabi Yusuf matur marang } \\
\text { ramane, yaiku Nabi Ya'kub mengkene: } \\
\text { Bapak!! Kawula salebetipun tilem supena } \\
\text { sumerep lintang sewelas, srengenge lan } \\
\text { rembulan sami nyembah dhateng kawula. }\end{array}$ & $\begin{array}{l}\text { Nutura sira hé Muhammad! Sejarah } \\
\text { Yusuf. Ya iku nalika Yusuf matur marang } \\
\text { ramanen Dhuh rama kula. Kula punika } \\
\text { supena sumerep lintang kathahipun } \\
\text { sewelas, sumerep srengéngé lan rembulan, } \\
\text { sami tumurun sangking langit lajeng sami } \\
\text { sujud dhateng kawula. }\end{array}$ \\
\hline $\begin{array}{l}\text { One day, the Prophet Joseph said to his } \\
\text { father, that is, the Prophet Jacob, such: } \\
\text { "Father! In my sleep, I saw in my dream } \\
\text { eleven stars, the sun and the moon worship } \\
\text { me." }\end{array}$ & $\begin{array}{l}\text { Tell, o Muhammad! The story of Joseph. } \\
\text { That is, when Joseph said to his father, "Oh } \\
\text { in number, I saw the sun and the moon } \\
\text { come down from the sky and then prostrate } \\
\text { themselves before me." }\end{array}$ \\
\hline
\end{tabular}

Table 2. Paraphrase of Q 12:4 in Al-Ibriz and Al-Iklïl.

This type of translation provides the meaning of the verse but without any attempt to meticulously follow the Arabic wording or to clearly mark the translator's additions. Rather, this is the kyai telling a story about what the Qur'an says. Names of speakers and addressees and small contextual details are provided alongside some narrative embellishment. The origin of this type of translation is just as clearly oral as that of the gandul translation; one can just imagine the kyai telling the story of Joseph to his students.

Q12:10 contains part of a dialogue between Joseph's brothers where they discuss how to dispose of him.

[One of Joseph's brothers] said, "Do not kill Joseph, but, if you must, throw him into the hidden depths of a well where some caravan may pick him up."

Al-Iklil takes these relatively dry words and, with a few small additions that have little impact on the meaning, adds emotion, emphasis and tension to the story:

Saweneh ana kang ngucap: Aja! Aja dipateni! Jegurna bae ana ing sumur guwa kang peteng, supaya mengko ditemu dening wong untan-untan. Aja dipateni! Cukup mengkono bae, menawa sira kabeh pancen padha karep misah Yusuf saking bapak.

'One of them said, “Don't! Don't kill him! Just throw him into a dark cistern so that he will later be found by a caravan. Don't kill him! It's enough to do it like that if you really want to separate Joseph from [our] father."'

The two kyais, especially Bisri Musthofa, sometimes add a considerable amount 
of such embellishment, even including additional pieces of dialogue. Misbah Mustofa has no qualms about turning the wolf that supposedly ate Joseph into a tiger so his audience can relate to the story. ${ }^{11}$

At the same time, the translators take great care not to stray too far from the Qur'anic text. They fill some of the ellipses in the Qur' an and add flavour to the story but they do not usurp it. If they want to present information that is a substantial addition to the story told in the Qur'an and not strictly needed to understand the latter, they present it in the third category of their commentaries which is clearly designated as exegetical content.

For example, Al-Iklil has several extensive stories concerning the brothers' ploy to let Joseph disappear, their claim that he was eaten by a wolf (or, in Misbah Mustofa's words, a tiger) and his survival in the cistern. According to these stories, Jacob sees through his sons' deception, asks God for the ability to talk to animals and then questions the predator that the brothers claim has eaten Joseph. Furthermore, Joseph is saved from the cold cistern because his father gave him a shirt with magical properties that he had inherited from Abraham, who in turn had received it from the angel Gabriel for protection from Nimrod's fire-pit. Al-Ibriz does not present additional narrative material on any of these topics but has several extensive stories on Joseph's time in Egypt, his life in Potiphar's household, Potiphar's wife's attempt to frame him for sexual misconduct, as well as his reign and his later reunion with his family. All this is clearly recognizable as extra-Qur'anic storytelling. Conversely, the second section of their works, in which the kyais paraphrase the Qur'an's meaning, could be labelled a narrative translation that relays the Qur'an's message in the kyais' voice.

Part of their immersion in the story and their effort to make it believable for the audience is their full use of the registers, honorifics and humilifics of the Javanese language, much in contrast to the gandul section where this is barely done, as has already been noted above. For example, in the gandul section, both kyais use the neutral bapak ('father' in ngoko and krama) to describe Jacob's relation to Joseph whereas in the narrative translation, they use the by far more respectful honorific rama, a krama inggil term. In the narrative translation, the characters behave like real persons in real social situations and therefore use the adequate register. The use of register functions contributes to turning Qur'an translation into storytelling. ${ }^{12}$

While in the gandul section, the kyai's voice is that of a grammar teacher, in the narrative translation, it is that of a storyteller who unabashedly presents his audience with his own version of what the Qur'an means. The rigidity and word-for-word method of the gandul system forces the translator to cling to the source text and largely prevents the omission of semantic and syntactic content

${ }^{11}$ Ricci (2016: 76) points out that translation moves "the Arabic text away from its place of origin, [...] to be reinscribed in very different natural and social environments that offered new frames of reference and interpretation; translation also 'moved' the Austronesian and local Malay and Javanese languages closer to a Semitic and sanctified Arabic."

${ }^{12}$ I discuss the use of register in the translation of Qur'anic dialogue into Javanese in a separate paper that will be published in an edited volume on the translation of the Qur'an in Indonesia. 
even when it might be deemed untranslatable; conversely, the narrative translation allows for the type of creativity and adaptation that is impossible in an interlinear translation, at the expense of precision (compare Ricci 2020).

The combined translation methodology of the kitab kuning foregrounds the kyais' voices and thereby raises a much lower claim to fidelity to the source text than the English translations cited above. At the same time, one might wonder whether it is not the more faithful method in some ways, precisely because the translator is not hidden and the source text is not replaced by a would-be equivalent. The voice of the source text's author is not transformed into something else; it is always the voice of the translator we are hearing, and the audience is kept aware of that fact.

\section{FROM SCHOOL TO MOSQUE}

While the kitab kuning might be considered a paradigmatically Javanese genre of tafsir, they are not the only one. The more conventional type of Qur'an translation, which seeks to render the translator invisible and claims faithfulness to the source text, exists as well.

At a conference in Yogyakarta in July 2018, a participant gave me one of a series of photocopied booklets, asking for advice on how to find a professional publisher. The series is composed of thirty booklets, conforming to the thirty parts of the Qur'an (Masjid al-Huda n.d.). They contain a translation - explicitly labelled as such (Tarjamah al-Qur'an basa jawi) - that is based on weekly Qur'an instruction which is given after Friday prayers at Al Huda mosque in Ngabeyan, which is located in the village of Margorejo in the district of Sleman in the Special Region of Yogyakarta. According to my interlocutor, the author was his grandfather who taught the Qur'an lessons at $\mathrm{Al} \mathrm{Huda}$ mosque. Thus, this work originated in a teaching context but not one in which mastery of the Islamic sciences was the aim of the lessons. This has a direct impact on the form and method of the translation even though, at first glance, there appear to be striking similarities to the kitab kuning. After all, it is essentially a combination of an interlinear translation and a paraphrase (see Figure 3); the main difference seems to be that there is no additional exegetical material. 


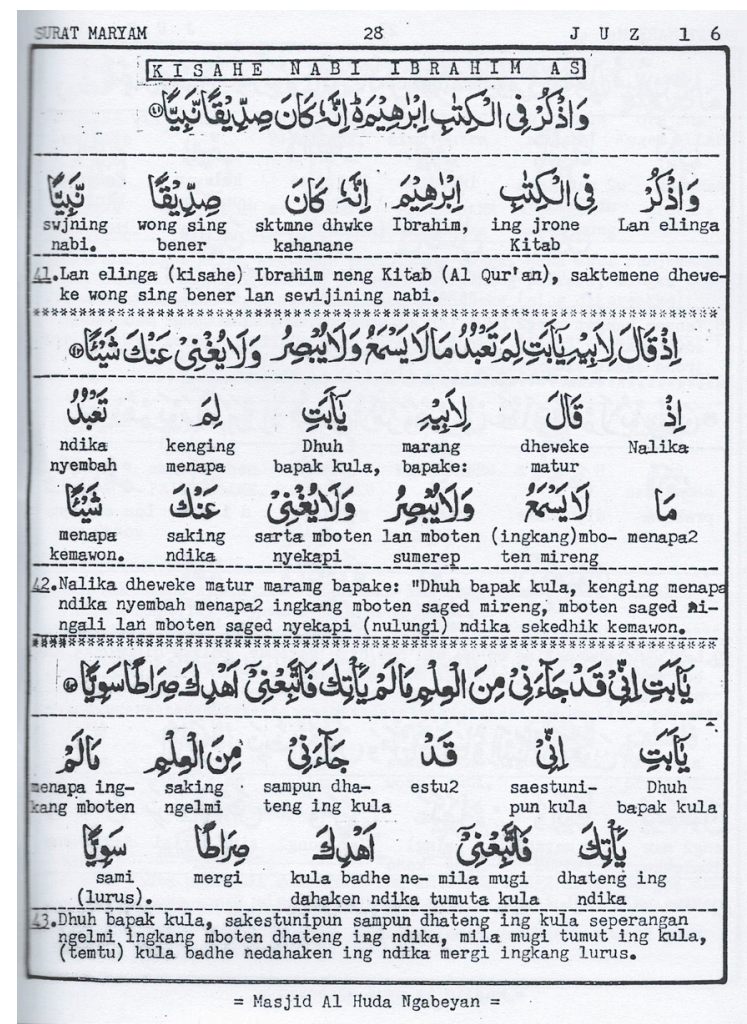

Figure 3. Page from the Masjid Al-Huda translation.

However, both the interlinear translation and the paraphrase in the Masjid Al-Huda translation follow a markedly different method from those employed in the kitab kuning. This becomes clear from a look at the Qur'anic story of the annunciation of Jesus.

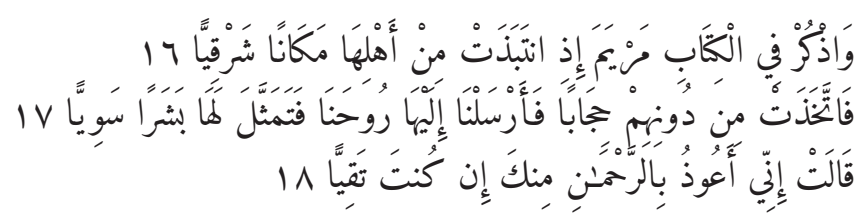

'16 And mention in the Scripture Mary, when she withdrew from her folk to a place east 17 and put up a screen between them and herself. We sent Our spirit to her and it appeared before her in the form of a perfect human. 18 She said, "Verily, I seek the Lord of Mercy's protection against you if you are God-fearing!"'

The Masjid al-Huda translates this as follows:

16 Lan elinga (kisahe) Maryam neng Kitab, nalika dheweke ninggalke seka kulawargane menyang sewijining panggonan ing sisih wetan 17 Mongka dheweke nganakke aling2 (ndhelik) seka wong2 mau, banjur Ingsun ngutus roh Ingsun (Malaikat Jibril) marang 
dheweke, mongke dheweke (Jibril) njilma ing ngarepe (ing wujud) menungsa sakbenere. 18 Maryam ngucap: "Saktemene aku ngayom seka sira marang (Pangeran) Sing Maha Murah, (sira aja ngganggu aku) yen sira wong sing taqwa."

'16 And remember (the story of) Mary in the Scripture, when she left her family for a place in the east 17 whereupon she set up a screen (to hide) from these people. Then We sent Our spirit (the Angel Gabriel) to her, whereupon he (Gabriel) manifested himself in front of her (in the shape of) a proper human. 18 Mary said, "Verily, I seek protection from you with the Most Merciful (Lord), (do not disturb me) if you are God-fearing."

This translation is very close to the Qur'anic wording, without any of the narrative expansion and embellishment that is characteristic of the kitab kuning. Explanatory additions are clearly marked by brackets. The closeness to the Arabic source text is additionally underlined by the fact that the paraphrase is extremely similar to the interlinear translation, as can be seen from the treatment of verse 16 (the verse runs from right to left, following the Arabic reading direction):

\begin{tabular}{|c|c|c|c|c|c|}
\hline شَرْقِيًَا & مَكَنًَا & مِنْ أَهَلْهَها & إِذِ انتَبَذَتْ & 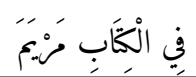 & وَاذْكُ \\
\hline siring wetan & $\begin{array}{l}\text { sewijining } \\
\text { panggonan }\end{array}$ & $\begin{array}{l}\text { seka } \\
\text { kulawargane }\end{array}$ & $\begin{array}{l}\text { nalika dhwk } \\
\text { [dheweke] } \\
\text { ninggalke }\end{array}$ & $\begin{array}{l}\text { ing Kitab } \\
\text { Maryam }\end{array}$ & Lan elinga \\
\hline
\end{tabular}

Table 3. Interlinear translation of Q 19:16 in the Masjid al-Huda Qur'an translation.

The interlinear translation is comprehensible by itself. It contains no grammatical information or technical terminology. The inclusion of both the complete verses and a word-for-word version of the Arabic Qur'an suggests that some ability to recite it is either assumed or aimed for but no mastery of Arabic grammar is required or taught.

In contrast to the kitab kuning, the mosque translation uses intermittent headlines that structure the Qur'anic text. With headers such as "Mary becomes pregnant without physical contact with a man" (vv. 16-21), "The birth of the Prophet Jesus" (vv. 22-26), "Accusations against Mary and her protection by Jesus" (vv. 27-33) and "Jesus is not the son of God, and the lot of the unbelievers" (vv. 33-40), readers are guided through the muṣhaf and its translation.

As such, this translation is extremely similar to mainstream Qur'an translations in Bahasa Indonesia. For example, the pervasive translation $\mathrm{Al}$ Qur'an dan terjemahnya by the Indonesian Ministry of Religion had section headers in its first and second editions, which are still widely available. Al-Qur'an dan terjemahnya also employs a similar style of translation that is characterized by extremely closeness to the Arabic text while its sparse explanatory additions are marked by brackets.

The Masjid Al-Huda translation is not a copy of or re-translation of $\mathrm{Al}$ - 
Qur'an dan terjemahnya, however. The content and placement of the headers and explanatory additions are completely different. While the Masjid Al-Huda translation is clearly an independent work, it draws on the methodology most commonly found in contemporary Indonesian Qur' an translation outside the pesantren environment. Even its interlinear translation is probably less inspired by the gandul tradition than by the resurgence of interlinear translations in the Indonesian language in recent decades. This happened in the context of an Islamization of society and the commodification of the Islam (Hasan 2009). The Qur'an was printed in ever glossier and more colourful copies with an increasing number of features. These were more and more often designed to facilitate recitation and memorization, rather than an understanding of the meaning of the Arabic text, which explains the growing popularity of interlinear translations. Just like the Masjid Al-Huda translation, they do not aim to teach Arabic grammar but limit themselves to giving the meaning of individual expressions.

The Masjid Al-Huda translation was produced not only in a completely different context from the kitab kuning but also several decades later, at a time when Bahasa Indonesia was pervasive in Javanese religious culture. It is therefore hardly surprising that the influence of the Indonesian-language Qur'an translations is clearly discernible in this work, not only from the incorporation of Malay vocabulary but also with regard to the dominant logic of the "invisible translator" in contemporary Qur'an translation.

\section{BluRRED BOUNDARIES: THE LAYERS OF MOHAMMED AdNAN's TRANSLATION}

The last case study concerns a work with a complex history that defies easy categorization. Mohammad Adnan (1889-1969)'s Tafsir al-Qur'an Suci (basa jawi) serves to question the notion that the authorship, publication date and purpose of a translation can always be determined, as I have assumed so far in this paper. It is not even clear whether this is a pedagogical Qur' an translation and whether it is a post-independence product. The edition I examine was published in 1981, which is clearly post-independence (Adnan 1985). From the fact alone that its author was long deceased at that point, it is obvious that the work has earlier roots, however. In fact, it has a history that predates its author.

Adnan himself was an eminent Muslim scholar of the late colonial and early Republican period. Born and raised in Solo's kraton (palace) milieu and having received a hybrid education, he played an important role in the newly established national system of higher religious education during the 1950s and 1960s, especially in Yogyakarta at the State Islamic Institute that was to become UIN Sunan Kalijaga much later. The first edition of his tafsir was published in 1923 or 1924 in pegon script. In 1953, he started reworking it but never finalized or published these efforts. His son Abdul Basith Adnan, with the help of some collaborators, collected his father's drafts, modernized and edited them. In 1981, he posthumously published his father's Qur'an translation in Latin script (Adnan 1985: 5; Gusmian 2017). For all intents and purposes, it 
is a translation of, rather than a commentary on, the Qur'an, despite the title tafsir. Maybe there are historical in addition to dogmatic reasons for choosing that title because the work has precursors.

Adnan's translation is very similar to that of Bagus Ngarpah (d. 1913), who earned some fame for possibly being the first producer of a printed Javanese translation of the Qur' an, which elicited some controversy at the time, around 1908, with even the Mufti of Batavia, Sayyid Uthman, weighing in on the issue (Ngarpah 1905; Kaptein 2014: 198-199). Bagus Ngarpah was the head teacher of the Manba' al-'ulūm school in Solo, which offered a modernized curriculum to children from the kraton milieu - the same milieu that Adnan came from. Bagus Ngarpah's Kuran Jawi was to be used as a textbook at that school alongside the Tafsir al-Jalālayn, probably to teach reading skills in the Javanese carakan and the Latin alphabet. As a matter of fact, Bagus Ngarpah might have done little more than converting an earlier Qur'an translation in pegon script into these scripts: the one by Kanjeng Raden Penghulu Tafsir Anom V (d. 1933), a scholar from the kraton of Solo (Surakarta) (Florida 2012: 248-249; Khamidah 2012: 32-64; Kanjeng Raden Penghulu Tafsir Anom V 2014). The latter's translation/tafsir was collected and edited by his sons, one of whom was Mohammad Adnan. Mohammad Adnan's translation, just like Bagus Ngarpah's, is thus in all likelihood an edited version of a work by Kanjeng Raden Penghulu Tafsir Anom V (Khamidah 2012: 58-64).

This explains the old-fashioned literary Javanese employed by Adnan as well as the conspicuous parallels between Bagus Ngarpah's and Mohammad Adnan's works which even extend to the explanations of words and technical terms. In the version published by Mohammed Adnan's son, these are presented in footnotes while Bagus Ngarpah integrated them with the text but their wording is near identical. The translations themselves are often identical similar, but there are frequent divergences which may be explained by the revisions made by Mohammed Adnan as well as his son's edits. That son, Abdul Basith Adnan, described his father as the original author of Tafsir al-Qur'an Suci but given the high degree of overlap with Bagus Ngarpah's work, that cannot be entirely true.

The relationship between Adnan's and Bagus Ngarpah's works might also explain, at least partially, why the former opted for the label tafsir despite the fairly low amount of interpretive content he offers. The controversy surrounding Bagus Ngarpah's work was based on the accusation that it was an illicit attempt, funded by kraton money, to create a Javanese equivalent of the Arabic Qur' an that it was designed to replace (Kaptein 2014: 198-199). This impression was probably reinforced both by the closeness of the translation to the source text and by the fact that the Arabic Qur'an was not included in the monolingual Javanese print of the translation, possibly because of the lack of access to Arabic, let alone bilingual, typesetting at the time, and maybe also because the focus of the book was on teaching Javanese literacy. Bagus Ngarpah, of course, maintained that his work was a tafsir r, rather than a translation, and therefore perfectly acceptable. 
There is little point in trying to determine whether that claim is true because any translation could be labelled tafsir; it is mainly a matter of semantics. What method does Adnan employ, though? Another look at the story of the annunciation of Jesus in Q 19:16-18 will give an impression.

16 And mention in the Scripture (the story of) Mary, when she withdrew from her folk to a place east 17 and put up a screen between them and herself. We sent Our spirit to her and it appeared before her in the form of a perfect human. 18 She said, "Verily, I seek the Lord of Mercy's protection against you; if you are God-fearing!"

Mohammed Adnan renders this passage as follows:

16 He Muhammad, sira nyritakna lelakone Maryam ana ing kitab (Quran), nalika dheweke (Maryam) ndhelik anenepi (sumingkir) ana ing panggonan sawetane Baitul Muqaddas saka para kawulawargane. 17 Dheweke (Maryam) mau nuli gawe aling-aling, dienggo ngaling-alingi para kawulawargane. Ingsun nuli ngutus Malaikat Jibril supaya nemoni Maryam, sarta tekane Jibril iku nyaru arupa manungsa kang sempurna. 18 Maryam banjur matur marang Malaikat Jibril: "Sayektosipun kula nyuwun reksa dhateng Ingkang Maha Welas saking panjenengan, menawi panjenengan bekti dhateng Panjenenganipun Allah, sampun ngantos kenging panggodha jalaran panjenengan."

'16 Oh Muhammad, tell the story of Mary in the book (Qur'an), when she (Mary) hid, secluding herself (going away) in a place east of Jerusalem from her family. 17 She (Mary) then made a screen for the purpose of hiding her family. We then sent the Angel Gabriel to find Mary, and when Gabriel arrived, he disguised himself in the shape of a perfect human. 18 Mary then said [in a highly deferential manner] to the Angel Gabriel, "Verily, I ask protection from the Most Merciful from you, if you fear God, Your Lord, so I should not be harassed because of you."'

While staying fairly close to the Qur'anic source text, Adnan's translation is noticeably longer. This is partly because he fills in information that is implied but not explicitly stated in the Qur'an, such as the names of speakers and addressees. He also makes small exegetical additions, such as rendering "a place east" as "a place east of Jerusalem" or clarifying the reason for which Mary seeks God's protection. His method of translation is therefore extremely similar to the narrative translation in the kitab kuning, with a comparable didactic purpose but in more literary Javanese and without any parallel attempt to make the Arabic Qur' an itself accessible. In this sense, it is plausible to consider it a tafsir because the narrative and interpretive dimensions are more pronounced than, for example, in Al-Qur'an dan terjemahnya or the Masjid Al-Huda translation.

At the same time, and despite the audibility of the translator's voice, it is unsurprising that Bagus Ngarpah's edition was seen by its critics as a translation that could be used without any recourse to the Arabic Qur'an because it could. It might not slavishly restrict itself to following the wording of the source text but it provides evidence that at a fairly early stage, some Javanese Muslims already saw a need to acquaint audiences who were unable 
to read the Arabic mușhaf with the meaning of the Qur' an and little more than that. This happened, of course, in a context of colonialism when new modes of education emerged, new notions of translation were spreading and literacy was more and more often acquired in Latin script.

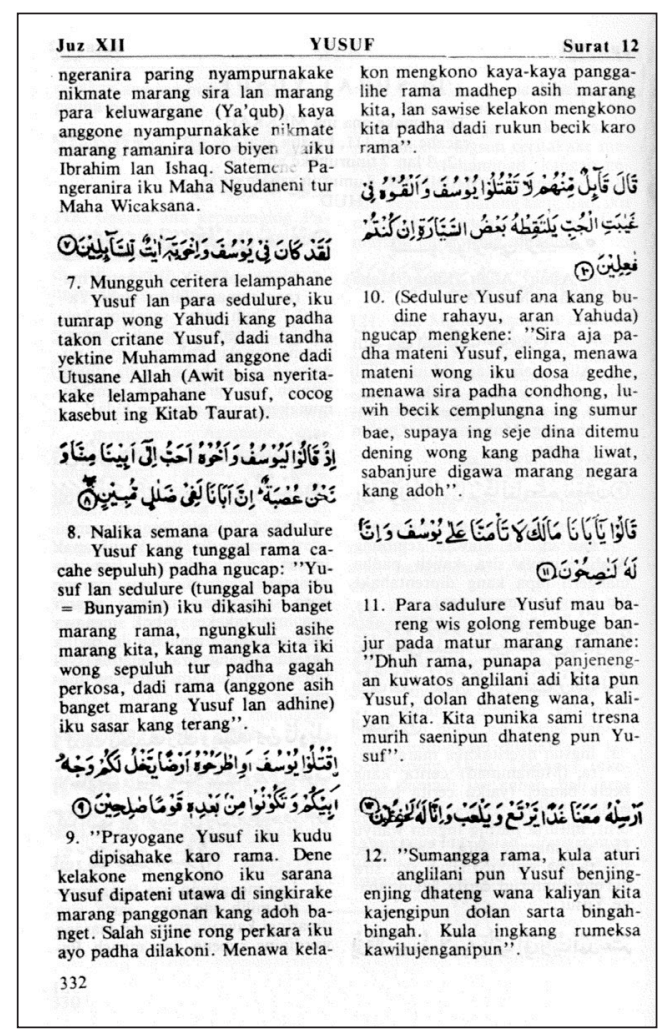

Figure 4. Page from Mohammad Adnan's Tafsir Al-Qur'an Suci (basa jawi).

However much the 1908 print edition of Bagus Ngarpah's work might have come across as a Qur'an translation, rather than a tafsir , to its critics, this is even more the case with the 1981 edition of Mohammed Adnan's book, despite its title. Adnan's son presents his father's paraphrase of the Qur' an's meaning in a manner that makes it readable as a continuous text (see Figure 4). He relegates the sparse amount of technical terminology or alternative translations to footnotes and places most - although not quite all - of the additions in brackets. For these reasons, Adnan's work comes across as a modern-style translation sui generis even if a close textual analysis demonstrates that it is more of a paraphrase or narrative translation. Presentation, script and typesetting contribute to the impression that this is a translation because, regardless of content, they have an effect on the functionality of the text and on readers' expectations (Pink 2017). The literary Javanese used by Adnan, which is in contrast to the oral Javanese employed by Bisri and Misbah Must(h)ofa, and the career of the author after independence in Islamic higher education further helped to convert this pedagogical work into a book to be read, rather than 
positioning it as part of a living oral tradition of teaching. But then, already by the time of Bagus Ngarpah, it seems to have been used to teach script, rather than oral skills in reciting and understanding the Qur'an.

By the same token, Abdul Basith Adnan presented Tafsir Qur'an Suci as his father's original creation, a single-author work, when in fact it has a long history involving multiple teachers. Like many works in Islamic intellectual history, it can neither be exclusively assigned to one individual author nor pinpointed to one year of origin. The 1981 edition of Mohammad Adnan's work is instructive because it imposes modern notions of both translation and authorship on a work that conforms to neither.

\section{CONCLUSION: TRANSLATION, EXEGESIS, AND ORALITY}

In this paper, I have discussed three styles of Javanese Qur'an translation: first, types of translation that stay close to the source text and hide the translator's voice, which are often called "literal" or "faithful" (Newmark 1988); second, grammatical translation as represented by the gandul system; and third, narrative translation in which the Qur'an's meaning is paraphrased in the translator's own words. From among those Javanese Qur'an translations that I have analysed, the first genre is represented by the most recent work, the Masjid al-Huda translation. It owes much to the dominant mode of Qur'an translation in the Indonesian language: direct and rather technical translations that follow the Arabic source text closely. They mark explanations and additions by brackets or relegate them to footnotes, and they prioritize the meticulous rendering of the Arabic text over expressiveness in the target language. In works such as the Masjid Al-Huda translation, the translator's aesthetic and exegetical voice is therefore heavily downplayed.

This type of translation might dominate the Indonesian field of Qur'an translation today, but it is not uncontested. When the famous literary critic H.B. Jassin wrote a Qur'an translation in the 1970s in a "poetic" style, this was a criticism of the dominant style of translation, however much H.B. Jassin's translation was itself criticized (Rahman 2005). And when the Islamist Muhammad Thalib published his "exegetical translation" (tarjamah tafsiriyah) in 2011, this was directly linked with an attack against the government translation, which he accused of being a "literal translation" (tarjamah harfiyah). According to Thalib, without including the authoritative interpretation of the Qur'an based on the tafsir tradition, a literal translation fails to be faithful to the text. It is rather the opposite, namely, misleading (Thalib 2011a, 2011b; Ikhwan 2015).

This is not the place to discuss Thalib's claims and their merit, or otherwise. They are, however, relevant to the present context because they involve a demand for making the translator's voice visible and thereby show that the dominant mode of Qur'an translation is not uncontested. In the Islamic field in Indonesia today, there is a broad discussion of the merits of "literal" translations versus such translations that aim at rendering the meaning, rather than the exact wording, of the Qur' an (tarjamah maknawiyah). While this 
categorization is rather ideological and analytically unhelpful, it highlights the fact that the notion of a "faithful" translation is slippery.

For one thing, meticulous closeness to the source text will not guarantee acceptance. In some cases, it is the exact opposite: it is the visible and audible voice of scholarly authority that ensures acceptance, whether through the kyai's narrative or the claim to present the consensus of exegetes.

For another, the perception or self-identification of a work as either a "literal translation" or a work of exegesis might not always correlate with the way in which the translator-exegete deals with specific problems in the Qur'an. This is because the text does not stand for itself and translating it is not merely a linguistic affair. The Qur'an is embedded in an exegetical tradition as well as a wider religious understanding, a legal and a theological discourse. For example, when the Qur'an talks of the "seat" or "throne" (kursi) of God in Q $2: 255$, this is not a semantic problem but a theological one, at least when one is opposed to anthropomorphism, as is the case with the theological school of Ash'arism which prevails in Indonesia. The supposedly literal Al-Qur'an dan terjemahnya has an issue with this while the supposedly exegetical Al-Ibriz does not. ${ }^{13}$

Is it realistic to expect a Muslim scholar to ignore his complete religious formation when translating the Qur'an? Would a Javanese translator ever think of "God's spirit" who comes to announce the birth of Jesus to Mary as anything but the angel Gabriel? And would their audiences consider this explanation a deviation from the source text or rather an enrichment to their understanding of it? On top of all that come the difficulties of reconstructing the "original meaning" of the Qur' anic text, which is far from straightforward, and of bridging the linguistic and cultural gap between seventh-century Arabia and contemporary Java.

One might discard Muhammad Thalib's intervention as a politicallymotived polemic, and probably rightly so, but his criticism points to a legitimate question that should be asked about Qur'an translation. That question is also relevant for the evaluation of the styles of translation found in the kitab kuning: how much sense does the notion of a "literal" or "faithful" or "direct" Qur'an translation make? Such notions abound in translation theory but if we try to apply them to Qur'an translations, what exactly would they refer to?

It is precisely because of these questions that I have been reluctant to assign a label to the style of translation that renders the translator invisible and demonstrates fidelity to the source text. Most categories offered by linguistic translation theories seem to be a poor fit. Is the Masjid Al-Huda translation a more "literal" or "faithful" one than the gandul translation in the kitab kuning? Does faithfulness to the source text demand the attempt to render the translator invisible, or is it not more honest to let the source text stand for itself and combine it with the self-conscious voice of the translator? Qur'an translation

${ }^{13}$ For an in-depth discussion of theological issues in Indonesian Qur'an translations in the Indonesian language, see Pink 2015. 
is always an attempt to make the Arabic source text accessible to a non-Arab audience. In some styles of translation, such as the gandul one, the audience's ability to understand the source text with some help is assumed. If it is not, they trust the translator to explain them the text's meaning. And if they trust the kyai's explanations, why should they not hear his voice?

We need to conceive of that voice as a spoken voice, and that is another reason for which it is difficult to apply standard translation theory to Javanese pedagogical Qur'an translation. The distinction, in English, between interpreting and translating applies here although the boundaries are blurred by the fact that oral exegesis is put into writing, and then printed. The result is both translation and interpretation because it has its origins in a teacher's oral lessons which are then converted into a book. That book still contains a text that was originally meant to be listened to, rather than read. It draws on the teacher's knowledge of an exegetical tradition that is referenced and summarized when it comes to mind but not systematically and literally cited. The reception of the resulting work is grounded in the speaker's authority. The authority of the teacher has, in the course of the past century or so, increasingly been challenged by the inherent authority of the printed text, which dominates much of the contemporary academic discourse on modern Islamic literature. The growing prestige of printed texts has doubtlessly informed the decision to produce Bisri Musthofa's kitab kuning as a glossy hard-cover work in Latin script. An oral interpretation by an individual teacher to a live audience is thus transformed into a medium targeting an anonymous readership, which exposes the text to expectations of "faithfulness" and turns a fluid and flexible genre of interpretation into a fixed, rigid text. Still, the kyai's voice remains distinct and discernible, a representation of an individual's effort to interpret the Qur'an at one moment in time and a reminder of the reconstructive work that any translator performs, even if it is sometimes well hidden.

The strong oral component in the Javanese tafsir texts is no coincidence. It is closely linked to the fact that Javanese has no official status in Indonesia and is relatively marginal to the production of printed text. Considering non-Western, non-standardized, and non-official languages not only serves as an incentive to think about the relationship between orality and writing in modern Islamic text production; it may also contribute to opening up our perspectives to a wide range of translation practices beyond the dominant mode of representing the source text.

\section{BIBLIOGRAPHY}

Tafsir al-Ibriz. 2020. “\#1.Tafsir Al-Ibriz - Surat Al Fatihah | KH. A. Mustofa Bisri (Gus Mus)". [Retrieved from: https://www.youtube.com/watch?v=aJcpuxXVAU; accessed on 17-04-2020.]

Abdel Haleem, M.A. S. (tr.). 2008. The Qur'an. Oxford: Oxford University Press. Adnan, Mohammad. 1985. Tafsir al-Qur'an Suci (basa jawi). Bandung: AlMa'arif.

Ali, Maulvi Muhammad. 1917. The Holy Qur-án; Containing the Arabic text with English translation and commentary. Woking: The "Islamic Review" office. 
Bruinessen, Martin van. 1990. "Kitab Kuning; Books in Arabic script used in the pesantren milieu", Bijdragen tot de Taal-, Land-en Volkenkunde 146: 226-269.

Bruinessen, Martin van. 2019a. "Madrasa in Southeast Asia", Encyclopaedia of Islam, THREE. Leiden: Koninklijke Brill NV. [Retrieved from: https:/ / doi.org/10.1163/1573-3912_ei3_COM_32325; accessed on 19-04-2020.]

Bruinessen, Martin van. 2019b. “Kiai”, Encyclopaedia of Islam, THREE. Leiden: Koninklijke Brill NV. [Retrieved from: https:/ / doi.org/10.1163/15733912_ei3_COM_35598; accessed on 18-04-2020.]

Bruinessen, Martin van. 2020. “Kitab Kuning”, Encyclopaedia of Islam, THREE. Leiden: Koninklijke Brill NV. [Retrieved from: https://doi. org/10.1163/1573-3912_ei3_COM_35640; accessed on 19-04-2020.]

Burhani, Ahmad Najib. 2015. "Sectarian translation of the Qur' an in Indonesia; The case of the Ahmadiyya", Al-Jami'ah; Journal of Islamic Studies 53(2): 251-282.

Calder, Norman. 1993. "Tafsìr from Tabarī to Ibn Kathīr; Problems in the description of a genre, illustrated with reference to the story of Abraham", in: Abdul-Kader Shareef and G. R. Hawting (eds), Approaches to the Qur'ān, pp. 101-140. London: Taylor and Francis.

Departemen Agama Republik Indonesia (ed.). 1965. Al Quräan dan Terdjemahnja. First edition, 3 vols. Jakarta: Departemen Agama Republik Indonesia.

Florida, Nancy K. 2012. Javanese literature in Surakarta manuscripts. Ithaca, NY: Cornell Southeast Asia Program Publications.

Gipper, Andreas. 2014. “Vertikales Übersetzen. Vom translatorischen Umgang mit Sakralsprache", Welt des Orients 44: 251-262.

Gusmian, Islah. 2015. Dinamika Tafsir al-Qur'an Bahasa Jawa abad 19-20 M. Surakarta: Efude.

Gusmian, Islah. 2016. “Tafsir al-Qur'an Bahasa Jawa; Peneguhan identitas, ideologi, dan politik", Subufuf 9(1): 141-168.

Gusmian, Islah. 2017. “K.H. Raden Muhammad Adnan (1889-1969 M); Ulama dan pejuang di bidang pendidikan, politik, dan agama dari Kauman Surakarta", Jurnal Lektur Keagamaan 15: 217-232.

Hasan, Noorhaidi. 2009. "The making of public Islam: piety, agency, and commodification on the landscape of the Indonesian public sphere", Contemporary Islam 3(3): 229-250.

Ikhwan, Munirul. 2015. “F̄̄ tahaddī al-dawla: 'Al-tarjama al-tafsīriyya' fī muwājahat al-khitāa al-dīnī al-rasmī li"1-dawla al-Indūnīsiyya”, Journal of Qur'anic Studies 15: 121-157.

Jones, Alan (tr.). 2007. The Qur'ān. Cambridge: Gibb Memorial Trust.

Kanjeng Raden Penghulu Tafsir Anom V. 2014. "Kanjeng Raden Penghulu Tafsir Anom V; Ulama yang menulis tafsir berbahasa Jawa dan berhuruf Jawa". [Retrieved from: https://www.facebook.com/notes/shohibul-faroji/ kanjeng-raden-penghulu-tafsir-anom-v-ulama-yang-menulis-tafsirberbahasa-jawa-da/317272161757077/; accessed on 19-04-2020.]

Kaptein, N.J.G. 2014. Islam, colonialism and the modern age in the Netherlands East Indies; A biography of Sayyid Uthman (1822-1914). Leiden: Brill. 
KH Bisri Musthofa. 2015. “KH Bisri Musthofa: Singa podium pejuang kemerdekaan". [Retrieved from: https://www.nu.or.id/post/read/64690/ kh-bisri-musthofa-singa-podium-pejuang-kemerdekaan; accessed on 1904-2020.]

Khamidah, Noor. 2012. "Studi analisis terhadap terjemah Kuran Jawi Bagus Ngarpah". BA thesis, Institut Agama Islam Negeri Walisongo, Semarang. Lukman, Fadhli. 2019. The state as the [sic] political interpreter; The history of alQur'an dan terjemahnya by the Indonesian Ministry of Religious Affairs. PhD thesis, Albert-Ludwigs-Universität Freiburg.

al-Maḥallī, Jalāl al-Dīn Muhammad and Jalāl al-Dīn 'Abd al-Raḥmān b. Abī Bakr al-Suyūțī. 1385 H. Al-Qur'ān al-karìm wa-fì hāmishih tafsìr al-imāmayn al-Jalālayn. Damascus: al-Maktaba al-hāshimiyya.

Martin, Richard C. 2002. "Inimitability", in: Jane Dammen McAuliffe (ed.), Encyclopaedia of the Qur'ān, Vol. 2, pp. 526-536. Leiden: Brill.

Masjid al-Huda. n.d. Tarjamah Al-Qur' an basa jawi. 30 vols. Ngabeyan.

Masrur, Mohammad. 2012. "Kyai Soleh Darat, Tafsir Fa'id al-Rahman, dan Ra. Kartini", Taqaddum 4. [Retrieved from: http:/ /journal.walisongo.ac.id/ index.php/attaqaddum / article/view/725; accessed on 19-04-2020.]

Mir, Mustansir. 1993. "The süra as a unity; A twentieth-century development in Qur'ān exegesis”, in: Abdul-Kader Shareef and G. R. Hawting (eds), Approaches to the Qur'ān, pp. 211-224. London: Routledge.

Muștafā, Bishrī. n.d. Al-Ibrīz li-ma'rifat tafsìr al-Qur'ān al-'azìz (Kudus: Manārā, n.d.). 3 vols. Kudus: Manārā.

Musthofa, Bisri. 2015. Al-Ibriiz lima' rifatil Qur'anil aziz bahasa jawa latin. Kudus: Menara.

Newmark, Peter. 1988. A textbook of translation. New York, NY: Prentice-Hall International.

Ngarpah, Bagus. 1905. Kuran Jawi. [Latin transcript of a carakan manuscript.]

Nurtawab, Ervan. 2009. “The tradition of writing Qur'anic commentaries in Java and Sunda", Suhuf 2(2): 163-192.

Nurtawab, Ervan. 2016. “Qur' anic translation in Malay, Javanese, and Sundanese; A commentary or substitution", in: Majid Daneshgar, Peter G. Riddell, and Andrew Rippin (eds), The Qur'än in Malay-Indonesian World; Context and Interpretation, pp. 39-58. London/New York, NY: Routledge.

Pink, Johanna. 2015. "'Literal meaning' or 'correct 'aqīda'? The reflection of theological controversy in Indonesian Qur'an translations”, Journal of Qur'anic Studies 17: 100-120.

Pink, Johanna. 2017. "Form follows function; Notes on the arrangement of texts in printed Qur'an translations", Journal of Qur'anic Studies 19: 138-150.

Rahman, Yusuf. 2005. "The controversy around H.B. Jassin; A study of his al-Quranu'l-Karim bacaan mulia and al-Qur' an al-Karim berwajah puisi", in: Abdullah Saeed (ed.), Approaches to the Qur'an in contemporary Indonesia, pp. 85-105. Oxford: Oxford University Press.

Ricci, Ronit. 2010. “On the untranslatability of 'translation'; Considerations from Java, Indonesia", Translation Studies 3(3): 287-301. 
Ricci, Ronit. 2014. "Story, sentence, single word; Translation paradigms in Javanese and Malay Islamic literature", in: Sandra Bermann and Catherine Porter (eds), A companion to translation studies, pp. 543-556. Chichester: John Wiley and Sons.

Ricci, Ronit. 2016. "Reading between the lines; A world of interlinear translation", Journal of World Literature 1: 68-80.

Ricci, Ronit. 2020. "Sound across languages", Philological Encounters 5: 97-111. Saleh, Walid A. 2004. The formation of the classical Tafsir tradition; The Qur'än commentary of al-Tha'labì (d. 427/1035). Leiden: Brill.

Sejarah dan Biografi. 2020. "Sejarah dan biografi lengkap KH. Bisri Mustofa. Waratsah al-ambiya". [Retrieved from: http://just4th.blogspot. com/2015/06/sejarah-dan-biografi -lengkap-kh-bisri.html; accessed on 18-04-2020.]

Shakir, M. H. 2009. The Holy Koran [Qur'an]. [Place of publication not identified]: Ezreads.net.

Supriyanto. 2016. “Kajian al-Qur'an dalam tradisi pesantren; Telaah atas Tafsir al-Iklîl fî Ma' ânî al-Tanzîl”, Tsaqafah 12: 281-298.

Thalib, Muhammad. 2011a. Al-Qur'anul Karim; Tarjamah Tafsiriyah. Memahami makna Al-Qur'an lebih mudah, cepat, dan tepat. Second edition. Yogyakarta: Ma'had an-Nabawy.

Thalib, Muhammad. 2011b. Koreksi tarjamah harfiyah al-Qur'an Kemenag RI. Tinjauan Aqidah, Syari'ah, Mu'amalah, Iqtishadiyah. Yogyakarta: Ma'had an-Nabawy.

Tymoczko, Maria. 2007. Enlarging translation, empowering translators. Manchester/Kinderhook, NY: St. Jerome.

Usmani, Muhammad Taqi. 2007. The meanings of the noble Qur'ān with explanatory notes. Karachi: Maktaba Ma' ariful Quran: Idaratul-Ma'arif.

Wahidi, Ridhoul. 2015. "Hierarki bahasa dalam Tafsir al-Ibrīz li Ma'rifah Tafsīr al-Qur'ān Al-'Azīz karya K.H. Bisri Musthofa", Șuḅuf 8(1): 141-160.

Woodward, Mark. 2014. Java, Indonesia, and Islam. Dordrecht: Springer.

Zadeh, Travis. 2012. The vernacular Qur'an; Translation and the rise of Persian exegesis. Oxford: Oxford University Press. 